TECHNICAL SCIENCES AND TECHNOLOGIES

$U D C 621.316$

DOI: $10.25140 / 2411-5363-2018-2(12)-189-195$

Petro Lezhnyuk, Iryna Hunko, Juliya Malogulko, Iryna Kotylko, Liudmyla Krot

\title{
MODELING OF COMPATIBLE WORK OF DISTRIBUTED POWER SOURCES OF ELECTRIC POWER AND CENTRALISED POWER SUPPLY
}

Urgency of the research. Current trends of distributed generation development in Ukraine indicate a rapid generation increase from renewable energy plants. Most developed countries gradually refuse from the fossil fuels use and invest more and more to the "green" energy. Therefore, there is a need for a detailed study of the operation conditions of distributed energy sources due to their instability, as well as the processes that arise in distribution electric networks with diverse types of distributed energy sources.

Target setting. In the producing process of power energy by distributed energy sources due to the increase in their number, there are situations where several renewable sources of energy operate to only one system of buses. Thus, such distributive networks acquire the features of a local power system, which complicates the control process of such systems, and also there is a problem with the electricity supply of consumers.

Actual scientific researches and issues analysis. The analysis of publications suggests that in literature more attention is paid to studying the operating modes of solar power plants, or small hydroelectric power plants. However, almost no attention was paid to the study of their co-operation work.

Uninvestigated parts of general matters defining. Only a few works are devoted to the study of the co-operation of the diverce sources of distributed energy sources in the local electrical systems. That is why, their impact on power distribution networks and on the grid in general has not been studied extensively.

The research objective. In this article was considered the influence of asynchronous generators on small hydroelectric power plants on the operation modes of distribution electrical networks, and were investigated the processes that are occurring in local power systems with different types of distributed energy sources.

The statement of basic materials. Based on the research results, was developed a computer model of a such system in the PS CAD software environment. Two solar stations and one small hydroelectric power station with an asynchronous generator were connected to the power supply. It was shown the simulation of two modes of operation: a joint operation of a small hydroelectric power station, two solar power stations and a power supply center; a joint operation of a small hydroelectric power plant, two solar power stations and a power supply disconnected.

Conclusions. As a result of computer simulation, it is shown that by switching on a small hydroelectric power plant with an asynchronous generator in the case of an emergency shutdown of centralized power supply, it is possible to restore the work of solar power plants, and thus partially or completely restore the power supply of consumers.

Keywords: local electrical systems; distributed energy sources; PS CAD; power supply.

Fig.: 3. Table: 1. References: 6.

Urgency of the research. In the $21^{\text {st }}$ century, energy consumption and environmental pollution caused by traditional power plants have become an important problem, resulting in climate change in the world. And the adverse natural and man-made effects of conventional energy contribute to the transition to renewable energy sources. The policy for increasing the share of electricity from non-traditional energy sources in European countries by 2020 is as follows: Latvia plans to increase the indicator to $42 \%$, Finland - to $38 \%$, Great Britain - to $15 \%$, Poland $-15 \%$, Slovakia - $14 \%$, Hungary - $13 \%$, etc.

For example, the Swedish government announced in 2015 that it plans to abandon the use of fossil fuels to become the world's first non-fossil fuel state. In the budget submitted for consideration to the government, almost $\$ 1$ billion was reserved for the installation of «green infrastructure» - solar panels and wind power plants. Costs for research were provided too including ones for improving the ways of storing electricity. Iceland, already provides itself with renewable energy by almost $100 \%$. This result has been achieved thanks to large-scale investments in hydropower and the production of geothermal energy. Germany plans to provide about $80 \%$ of the energy needed from renewable sources by 2050 . According to the UN, by the middle of the century it will be possible to provide more than half of human energy needs at the expense of renewable sources. The use of renewable energy sources is one of the most important directions of Ukraine's energy policy. Due to this direction, the country's traditional fuel and energy resources are saved.

Target setting. In the last decade there has been a sharp increase in the generation capacity of distributed energy sources. Their parallel operation with the power system causes

С Лежнюк П. Д., Гунько І. О., Малогулко Ю. В., Котилко І. В., Крот Л. Р., 2018 
TECHNICAL SCIENCES AND TECHNOLOGIES a some problems, when several renewable energy sources work on only one system of buses, forming a local power system. This leads to significant problems with consumer supply.

Actual scientific researches and issues analysis. Analyzing the experience of foreign countries, the peculiarities of the climate and the geographical location of the Vinnytsia region, we came to the conclusion that it is advisable to use alternative sources of electricity such as water and sun. Vinnytsya region takes the leading position in the development of RES in distribution networks. The increase in their number leads to situations when several RES operate on one system of buses. Thus, such distributive networks acquire the features of a local power system (LPS).

Uninvestigated parts of general matters defining. In view of the fact that in most of the scientific papers in this area almost no attention is paid to the study of the co-operation of distributed energy sources generation in local electrical systems, then there is a need to investigate in detail the influence of such sources to the distributive power network [1-3].

The research objective. In order to study the processes occurring in distributed electric networks with different types of distributed energy sources, a computer model of such an LPS in the software environment PS CAD (Power System Simulation) was developed.

An analysis of foreign sources suggests that this software environment is widely used to simulate the operation of power grids in which distributed energy sources are exploited. PS CAD is a fast, accurate and simple tool for simulating power systems and power electronic converters when designing, analyzing, optimizing and verifying them. The PS CAD program offers a wide range of tools and a large library of components for detailed analysis of electrical equipment [4-6].

The statement of basic materials. Let's consider a model of a local electrical system, when two solar power plants (SPP) and one small hydroelectric power plant (SHPP) with an asynchronous generator (AG) are connected to one feeder (Fig. 1).

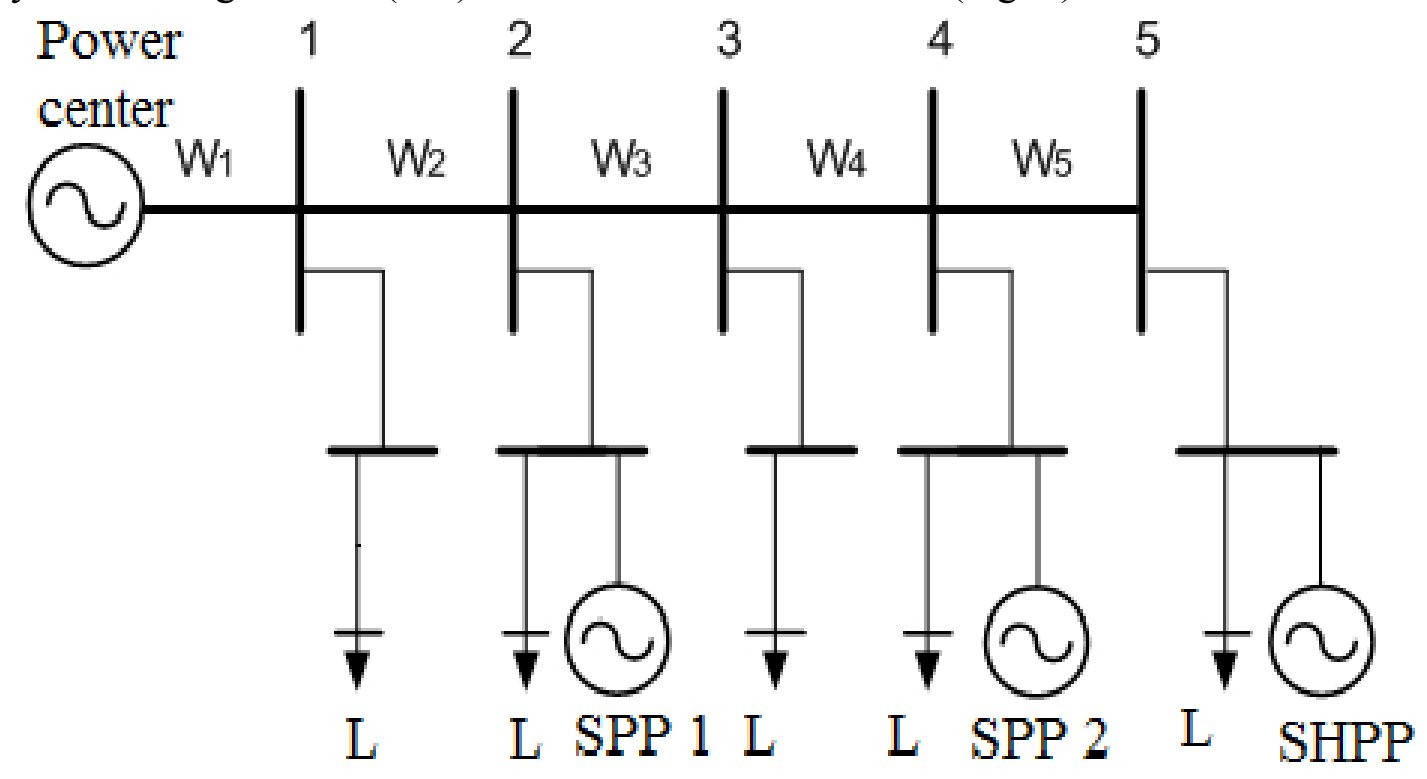

Fig. 1. Model of local 10/0.4 kV electric system

Under this scheme a model of 10/0.4 kV LPS was designed in software complex PSCAD. Computer model of the local electrical system contains $150 \mathrm{~kW}$ SHPP, two 2 MW SPP (SPP model diagram is shown in Fig. 2), five transmission lines for power consumers, the battery of static capacitors (BSC) to compensate reactive power (Fig. 3). 


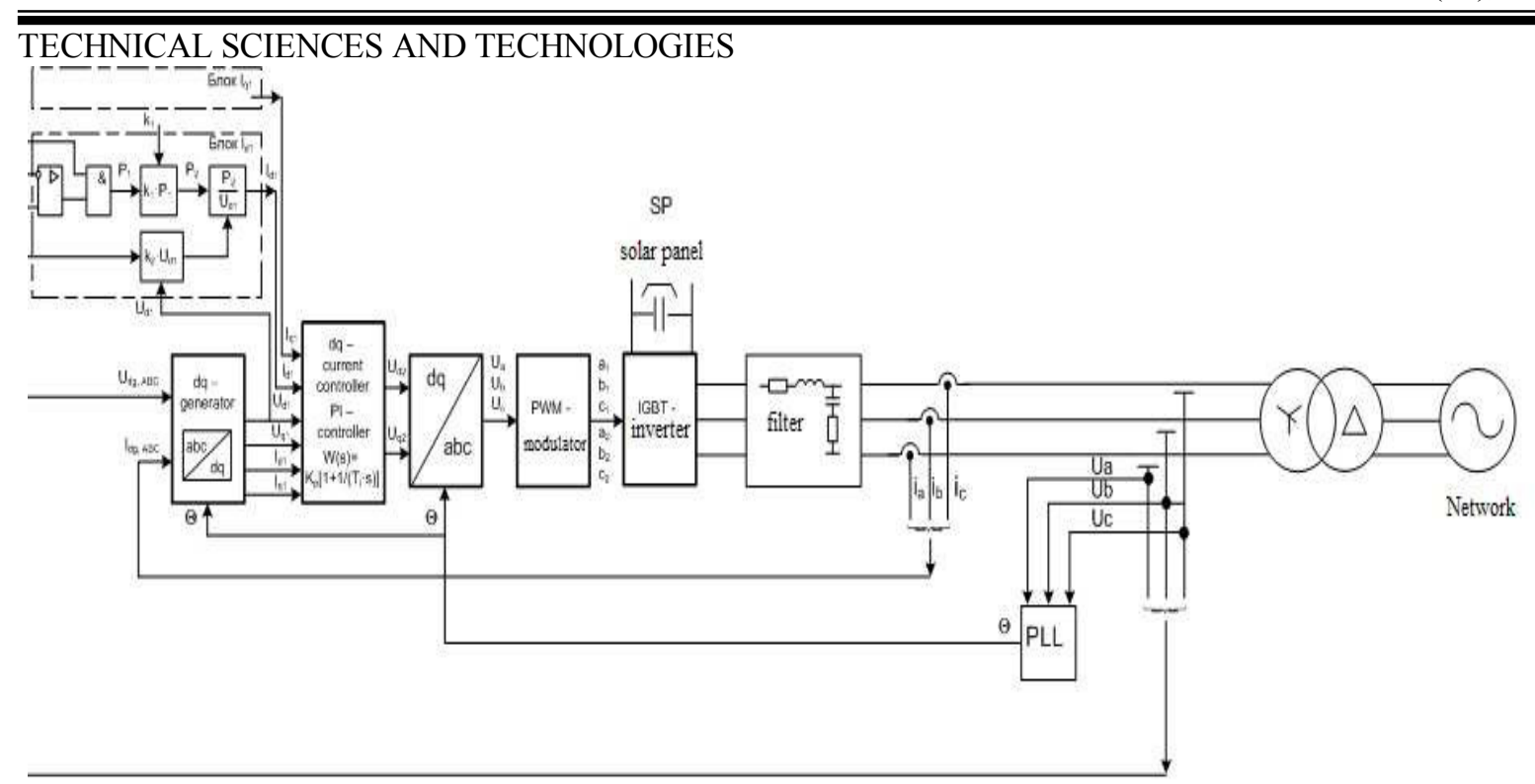

Fig. 2. Schematic diagram of the SPP with PI controller in PS CAD

The two modes of operation were simulated:

1) joint work of the SHPP, two SPPs and centralized power supply;

2) the joint work of the SHPP, two SPPs with the disconnected centralized power supply.

The simulation results are given in Table.

For the purpose of studying the influence of distributed power sources on load and voltage of $0.4 \mathrm{kV}$ buses, simulation of the mode of joint operation of the SHPP, $\mathrm{SPP}_{1}, \mathrm{SPP}_{2}$ and centralized power supply was carried out.

When the centralized power supply is disconnected, we run SHPP with asynchronous generator, from which the voltage is applied to solar power inverters and runs $\mathrm{SPP}_{1} \mathrm{SPP}_{2}$ restoring the power supply for consumers.

Table

Simulation results of modes

\begin{tabular}{|c|c|c|c|c|c|c|}
\hline \multirow{2}{*}{$\begin{array}{c}\text { № } \\
\text { experiment }\end{array}$} & System & $\mathrm{SPP}_{1}$ & $\mathrm{SPP}_{2}$ & SHPP & Load & \multirow{2}{*}{ Notes } \\
\hline & $\mathbf{P}$ & $\mathbf{P}$ & $\mathbf{P}$ & $\mathbf{P}$ & $\mathbf{P}$ & \\
\hline \multirow{5}{*}{1.} & \multirow{5}{*}{0,335} & \multirow{5}{*}{1,975} & \multirow{5}{*}{2,033} & \multirow{5}{*}{0,200} & 1. 1,556 & \multirow{5}{*}{$\begin{array}{l}\text { with centralized power } \\
\text { supply }\end{array}$} \\
\hline & & & & & 2. 0,984 & \\
\hline & & & & & 3. 1,403 & \\
\hline & & & & & 4. 0,170 & \\
\hline & & & & & $\sum=4,113$ & \\
\hline \multirow{5}{*}{2.} & \multirow{5}{*}{-} & \multirow{5}{*}{2,008} & \multirow{5}{*}{1,986} & \multirow{5}{*}{0,159} & 1. 1,478 & \multirow{5}{*}{$\begin{array}{l}\text { without centralized power } \\
\text { supply }\end{array}$} \\
\hline & & & & & 2. 0,964 & \\
\hline & & & & & 3. 1,452 & \\
\hline & & & & & 4. 0,212 & \\
\hline & & & & & $\sum=4,106$ & \\
\hline
\end{tabular}




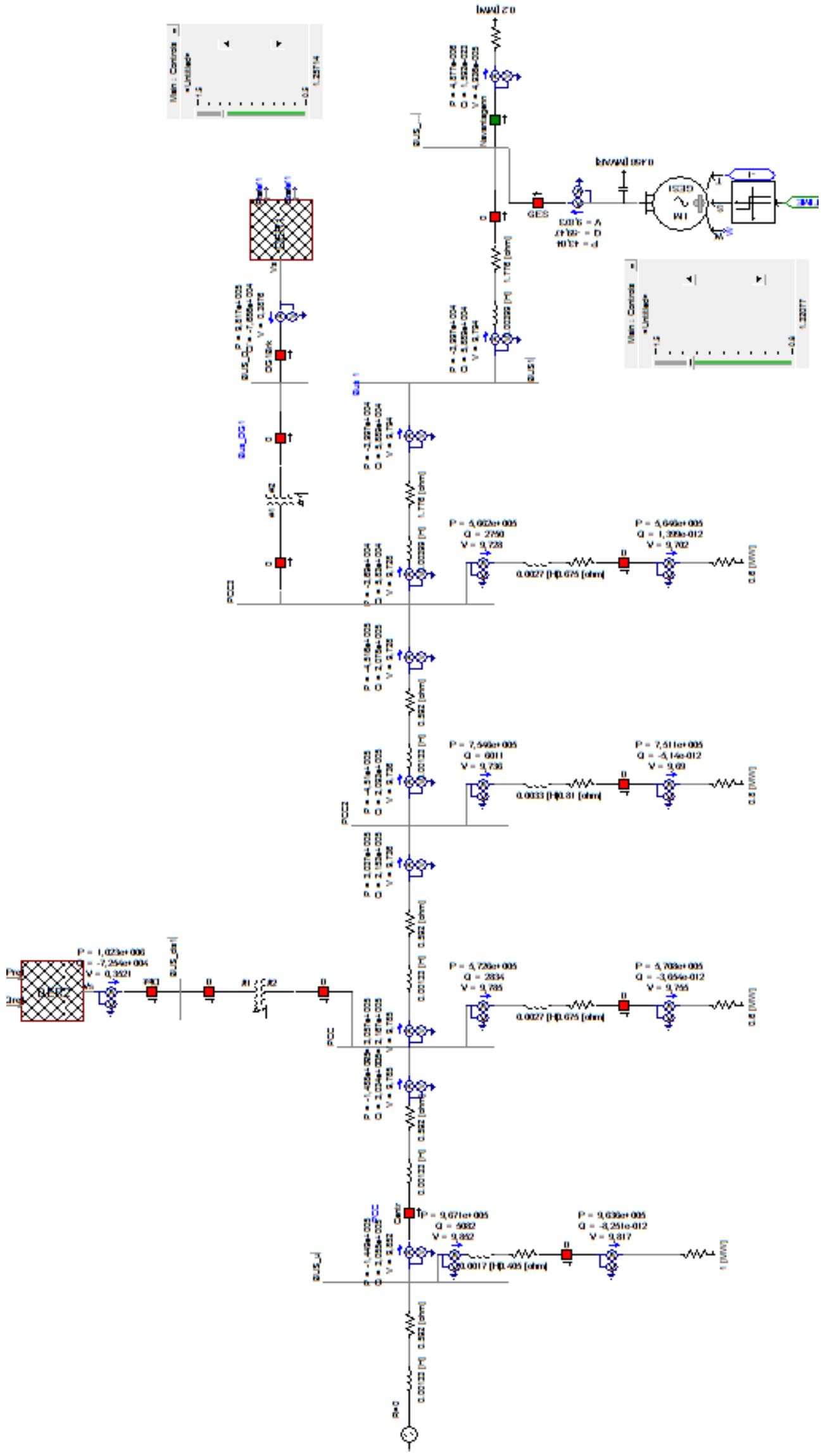

Fig. 3. Schematic computer model of $10 / 0.4 \mathrm{kV} L P S$ in PS CAD 
TECHNICAL SCIENCES AND TECHNOLOGIES

Conclusions. Consequently, by switching on a small hydroelectric power plant with an asynchronous generator in the case of an emergency shutdown of centralized power supply, it is possible to restore the work of solar power plants, and thus partially or completely restore the power supply of consumers.

\section{References}

1. Lezhniuk, P., Kulyk, V., Kovalchuk, O. (2011). Optimal control of distributed sources of energy in the local electrical system. Proceedings of the Institute of Electrodynamics of NAS of Ukraine. Collected works. Special Issue, 1, 48-55 [in English].

2. Kozyrskyi, V. V., Tuhai, Yu. I., Bodunov, V. M., Hai, O. V. (2011). Intehratsiia ponovliuvanykh dzherel enerhii $\mathrm{v}$ rozpodilni elektrychni merezhi silskykh rehioniv [Integration of renewable energy sources into distributive electric networks in rural regions]. Tekhnichna elektrodynamika - Technical electrodynamics, 5, 63-67 [in Ukrainian].

3. Lezhniuk, P., Kulyk, V., Burykin, O., Rubanenko, O., Malogulko, Yu. (2018). Optimization of the functioning of the renewable energy sources in the local electrical systems. Vinnitsa: VNTU [in English].

4. Fundamentals of PSCAD and General Applications. Retrieved from http://www.nayakcorp. com/Getting_Started42.ppt.

5. Makarenko, V. (2013). Prohrammnaia sreda modelyrovanyia enerhosystem PSCAD [The software environment for modeling power systems]. Modelirovanie radioelektronnyih ustroystv Simulation of radio electronic devices, 11, 44-48 [in Russian].

6. Lezhniuk, P., Rubanenko, O., Hunko, I. (2015). Vplyv invertoriv SES na pokaznyky yakosti elektrychnoi enerhii v LES [Influence of SPP inverters on indicators of quality of electric energy in LES]. Bulletin of the Khmelnytsky National University. Series: Engineering. Visnyk Khmelnytskoho natsionalnoho universytetu. Seriia: Tekhnichni nauky, 2, 134-145 [in Ukrainian].

\section{References (in language original)}

1. Lezhnyuk P. Optimal control of distributed sources of energy in the local electrical system / P. Lezhnyuk, V. Kulik, O. Kovalchuk // Proceedings of the Institute of Electrodynamics of NAS of Ukraine. Collected works. Special Issue. Part 1. - 2011. - P. 48-55.

2. Інтеграція поновлюваних джерел енергії в розподільні електричні мережі сільських регіонів / В.В.Козирський, Ю. І. Тугай, В. М. Бодунов, О.В.Гай // Технічна електродинаміка. 2011. - № 5. - С. 63-67.

3. Optimization of the functioning of the renewable energy sources in the local electrical systems / P. Lezhniuk, V. Kulyk, O. Burykin, O. Rubanenko, Yu. Malogulko. - Vinnitsa: VNTU, 2018. - 124 p.

4. Fundamentals of PSCAD and General Applications [Електронний ресурс]. - Режим доступу : http://www.nayakcorp.com/Getting_Started42.ppt.

5. Макаренко B. Программная среда моделирования энергосистем PSCAD / В. Макаренко // Моделирование радиоэлектронных устройств.- 2013. - № 11. - С. 44-48.

6. Лежнюк П. Д. Вплив інверторів СЕС на показники якості електричної енергії в ЛЕС / П. Д. Лежнюк, О. Є. Рубаненко,І. О.Гунько // Вісник Хмельницького національного університету. Серія: Технічні науки. - 2015. - № 2. - С. 134-145.

\section{УДК 621.316}

\section{Петро Лежнюк, Ірина Гунько, Юлія Малогулко, Ірина Котилко, Людмила Крот \\ МОДЕЛЮВАННЯ СУМІСНОЇ РОБОТИ РОЗОСЕРЕДЖЕНИХ ДЖЕРЕЛ ЕЛЕКТРОЕНЕРГІЇ ТА ЦЕНТРАЛІЗОВАНОГО ЕЛЕКТРОПОСТАЧАННЯ}

Актуальність теми дослідження. Сучасні тендениії розвитку розосередженого генерування в Україні свідчать про стрімке зростання генерованих потужностей електричними станціями, які використовують відновлювану енергію. Більшість розвинених країн поступово відмовляються від використання викопного палива та все більше коштів інвестують у «зелену» енергетику. Тому є потреба детального дослідження умов роботи розосереджених джерел генерування через їхню нестабільність, а також процесів, щэо виникають у розподільних електричних мережах із різнотипними розосередженими джерелами енергії.

Постановка проблеми. У процесі виробництва електричної енергї̈ джерелами розосередженого генерування в зв'язку зі зростанням їх кількості виникають ситуачій, коли декілька відновлюваних джерел енергії прачюють лише на одну систему шин. Таким чином, такі розподільні мережі набувають рис локальної електроенергетичної системи, щьо ускладнює процес керування такими системами, а також виникає проблема з електропостачанням споживачів. 
Аналіз останніх досліджень і публікацій. Аналіз публікачій свідчить про те, щзо в літературних джерелах більще уваги приділяється або дослідженню режсимів роботи сонячних станцій, або малих гідроелектростаниій. Проте майже не приділено уваги дослідженню їхній сумісної роботи.

Виділення недосліджених частин загальної проблеми. Дуже мало робіт присвячено дослідженню сумісної роботи різнотипних джерел розосередженого генерування в локальних електричних системах. У зв'язку з ијм майже не досліджено їх вплив на розподільні електричні мережі та на енергосистему загалом.

Постановка завдання. У статті розглянуто вплив асинхронних генераторів на малих гідроелектростанціях на режими роботи розподільних електричних мереж, а також досліджено процеси, які виникають у локальних енергосистемах із різнотипними розосередженими джерелами енергії.

Виклад основного матеріалу. На основі результатів дослідження розроблено комп 'ютерну модель такої системи в програмному середовищі PS CAD. До иеентру жсивлення було приєднано дві сонячні станиії та одну малу гідроелектростаниію з асинхронним генератором. Проведено моделювання двох режимів роботи: сумісної роботи малої гідроелектростаниії, двох сонячних електростанцій та центру живлення; сумісної роботи малої гідроелектростанції, двох сонячних електростаниій та із відключеним цеентром живлення.

Висновки відповідно до статті. У результаті комп'ютерного моделювання показано, ще у випадку аварійного відключення изентралізованого електропостачання за допомогою увімкнення малої гідроелектростаниії з асинхронним генератором можна відновити роботу сонячних електростанцій, а таким чином частково або повністю відновити електропостачання спожсивачів.

Ключові слова: локальна енергосистема; джерела розосередженого генерування; PS CAD; електропостачання.

Рис.: 3. Табл.: 1. Бібл.: 6.

УДК 621.316

\section{Петр Лежнюк, Ирина Гунько, Юлия Малогулко, Ирина Котилко, Людмила Крот МОДЕЛИРОВАНИЕ СОВМЕСТНОЙ РАБОТЫ РАССРЕДОТОЧЕННЫХ ИСТОЧНИКОВ ЭЛЕКТРОЭНЕРГИИ И ЦЕНТРАЛИЗОВАННОГО ЭЛЕКТРОСНАБЖЕНИЯ}

Актуальность темы исследования. Современные тенденции развития рассредоточенного генерирования 8 Украине свидетельствуют о стремительном росте генерируемых мощностей электрическими станциями, которые используют возобновляемую энергию. Большинство развитых стран постепенно отказываются от использования ископаемого топлива и все больше инвестируют в «зеленую» энергетику. Поэтому существует потребность детального исследования условий работы рассредоточенных источников генерачии в связи с их нестабильностью, а также процессов, возникающих в распределительных электрических сетях с разнотипными рассредоточенными источниками энергии.

Постановка проблемы. В прочессе производства электрической энергии источниками рассредоточенного генерирования в связи с возрастанием их количества возникают ситуачии, когда несколько возобновляемых источников энергии работают только на одну систему шин. Таким образом, такие распределительные сети приобретают черты локальной электроэнергетической системы, что затрудняет прочесс управления такими системами, а также возникает проблема с электроснабжением потребителей.

Анализ последних исследований и публикаций. Анализ публикаций свидетельствует о том, что в литературных источниках больше внимания уделяется или исследованию режимов работы солнечных станций, или мальх гидроэлектростанций. Однако почти не уделено внимания исследованию их совместной работы.

Выделение неисследованных частей общей проблемы. Очень мало работ посвящено исследованию совместной работы разнотипных источников рассредоточенного генерирования в локальных электрических системах. В связи с этим почти не исследовано их влияние на распределительные электрические сети и на энергосистему в целом.

Постановка задачи. В статье рассмотрено влияние асинхронных генераторов на малых гидроэлектростанииях на режимы работы распределительных электрических сетей, а также исследованы прочессы, возникающие в локальных энергосистемах с разнотипными рассредоточенными источниками энергии.

Изложение основного материала. На основе результатов исследования разработана компьютерная модель такой системы в программной среде PS CAD. К иентру питания были присоединены две солнечные станции и одна малая гидроэлектростаниия с асинхронным генератором. Проведено моделирование двух режимов работы: совместной работы малой гидроэлектростанции, двух солнечных электростанций и центра питания; совместной работы малой гидроэлектростанции, двух солнечных электростанций и с отключенным центром питания.

Выводы в соответствии со статьей. В результате компьютерного моделирования показано, что в случае аварийного отключения иентрализованного электроснабжения посредством включения малой гидроэлектростанции с асинхронным генератором можно восстановить работу солнечных электростанций, а таким образом частично или полностью восстановить электроснабжение потребителей.

Ключевые слова: локальная энергосистема; источники распределительного генерирования; PS CAD; электроснабжение.

Рис.: 3. Табл.: 1. Библ.: 6. 
Lezhnyuk Petro - Doctor of Technical Sciences, Professor, Head of the Department of Electrical Stations and Systems, Vinnitsa National Technical University (95 Khmelnytsky highway, 21000 Vinnitsa, Ukraine).

Лежнюк Петро Дем'янович - доктор технічних наук, професор, завідувач кафедри електричних станцій і систем, Вінницький національний технологічний університет (Хмельницьке шосе, 95, м. Вінниця, 21000, Україна).

Лежнюк Петр Демьянович - доктор технических наук, профессор, заведующий кафедры электрических станций и систем, Винницкий национальный технический университет (Хмельницкое шоссе, 95, г. Винница, 21000, Украина).

E-mail: lezhpd@gmail.com

Hunko Iryna - PhD in Technical Sciences, senior lecturer of the Department of Electrical Stations and Systems, Vinnitsa National Technical University (95 Khmelnytsky highway, 21000 Vinnitsa, Ukraine).

Гунько Ірина Олександрівна - кандидат технічних наук, старший викладач кафедри електричних станцій та систем, Вінницький національний технологічний університет (Хмельницьке шосе, 95, м. Вінниця, 21000, Україна).

Гунько Ирина Александровна - кандидат технических наук, старший преподаватель кафедры электрических станций и систем, Винницкий национальный технический университет (Хмельницкое шоссе, 95, г. Винница, 21000, Украина).

E-mail: iryna hunko@ukr.net

Malogulko Juliya - PhD in Technical Sciences, Associate Professor of the Department of Electrical Stations and Systems, Vinnitsa National Technical University (95 Khmelnytsky highway, 21000 Vinnitsa, Ukraine).

Малогулко Юлія Володимирівна - кандидат технічних наук, доцент кафедри електричних станцій та систем, Вінницький національний технологічний університет (Хмельницьке шосе, 95, м. Вінниця, 21000, Україна).

Малогулко Юлия Владимировна - кандидат технических наук, доцент кафедры электрических станций и систем, Винницкий национальный технический университет (Хмельницкое шоссе 95, г. Винница, 21000, Украина).

E-mail: Juliya_Malogulko@ukr.net

ORCID: http://orcid.org/0000-0002-6637-7391

ResearcherID: I-9097-2018

Scopus Author ID: 57193505644

Kotylko Iryna - methodist of the $2^{\text {nd }}$ category in Educational-Methodical Department, Vinnitsa National Technical University (95 Khmelnytsky highway, 21000 Vinnitsa, Ukraine).

Котилко Ірина Вадимівна - методист 2-ї кат. навчально-методичного відділу, Вінницький національний технологічний університет (Хмельницьке шосе, 95, м. Вінниця, 21000, Україна).

Котилко Ирина Вадимовна - методист 2-й кат. учебно-методического отдела, Винницкий национальный технический университет (Хмельницкое шоссе, 95, г. Винница, 21000, Украина).

E-mail: i.kotylko@gmail.com

Krot Liudmyla - student, Vinnitsa National Technical University (95 Khmelnytsky highway, 21000 Vinnitsa, Ukraine).

Крот Людмила Русланівна - студентка, Вінницький національний технічний університет (Хмельницьке шосе, 95, м. Вінниця, 21000, Україна).

Крот Людмила Руслановна - студентка, Винницкий национальный технический университет (Хмельницкое шоссе 95, г. Винница, 21000, Украина).

E-mail:2e.krot2015@gmail.com

Lezhnyuk, P., Hunko, I., Malogulko, Ju., Kotylko, I., Krot, L. (2018). Modeling of compatible work of distributed power sources of electric power and centralised power supply. Technical sciences and technologies, 2 (12), 189-195. 